\title{
Hermeneutika Peleburan Dua Horizon Anthony Thiselton dan Tantangan dari Antropologi Lintas Budaya
}

\author{
Ferry Y. Mamahit \\ Sekolah Tinggi Teologi SAAT, Malang \\ Korespondensi: ferry.mamahit@seabs.ac.id
}

\begin{abstract}
Abstrak: Masalah klasik dalam hermeneutika alkitabiah adalah pada kesulitan menjembatani kesenjangan antara teks Alkitab yang berkonteks budaya kuno dan pembacanya yang berkonteks budaya modern. Untuk mengatasi hal ini, Anthony Thiselton mengembang model peleburan dua horizon (the fusions of two horizons) yang awalnya didasari pada proposal yang sebelumnya yang disebut model peleburan horizon-horizon (the fusions of horizons). Meskipun pendekatan hermeneutis ini komprehensif dan serius dalam menjembatani kesenjangan ini, pendekatan konteks berkultur tunggalnya (baca: budaya Barat) ini belum dapat menjawab tantangan dari antropologi lintas budaya, khususnya kompleksitas konteks budaya pembaca modern yang berkarakteristik beragam, berlapis dan bersilang. Jadi, pendekatan ini perlu mempertimbangkan pendekatan hermeneutis yang lebih sensitif terhadap kompleksitas tersebut sebagai tambahan atau pelengkap terhadap pendekatan peleburan horizon-horizon (addenda hermeneutica).
\end{abstract}

Kata-kata kunci: Anthony Thiselton, Hermeneutika Alkitabiah, Peleburan-peleburan Horizon, Kompleksitas Konteks Budaya, Hermeneutika Kontekstual

Abstract: The classic problem in biblical hermeneutics is on the difficulty of bridging the gap between the ancient cultural context of the biblical texts and the modern cultural context of the reader. To deal with it, Anthony Thiselton developed the model of the fusion of two horizons initially based on an earlier proposal called the fusion of two horizons. Albeit comprehensive and severe in bridging the gap, his mono-cultural (Western) approach to the context has not yet answered the challenge from cross-cultural anthropology, especially the complexity of the culture of the modern reader that is varied, multi-layered and cross-cultural in its characteristics. The approach thus needs to consider a hermeneutical approach that is more sensitive to that complexity as addition into or compliment to the fusions of horizons approach (addenda hermeneutica).

Keywords: Anthony Thiselton, Biblical Hermeneutics, The Fusions of Horizons, The Complexity of Cultural Context, Contextual Hermeneutics 


\section{PENDAHULUAN}

Dalam beberapa dekade belakangan ini telah bermunculan berbagai buku hermeneutika yang menolong banyak orang untuk mengerti apa penafsiran Alkitab dan bagaimana menafsirkannya. ${ }^{1}$ Sayangnya, beberapa di antaranya sudah dianggap cukup kuno dan tidak relevan untuk situasi sekarang ini. Sebaliknya, beberapa yang lain masih dianggap terlalu teoretis dan terkesan sangat maju (advanced) bagi pembaca awam. ${ }^{2}$ Di samping beberapa keberatan terhadap beberapa referensi yang sudah ada ini, masih ada masalah klasik lain yang cukup penting dalam hermeneutika alkitabiah modern: bagaimana menjembatani kesenjangan hermeneutis (hermeneutical gap) antara teks sebagai produk masa lampau dan konteks pembaca masa kini. ${ }^{3}$

Salah satu dari para sarjana yang prihatin terhadap isu kesenjangan teks dan konteks ini adalah Anthony Thiselton. Dua karya monumentalnya, The Two Horizons in Hermeneutics (1980) dan New Horizons in Hermeneutics (1992), secara komprehensif dan serius mencoba untuk memberi solusi terhadap persoalan di atas. Menurutnya, persoalan kesenjangan ini harus diselesaikan dengan cara meleburkan dua horizon (horizon teks alkitabiah kuno dan horizon pembaca modern). ${ }^{4}$

${ }^{1}$ Beberapa di antaranya adalah Protestant Biblical Interpretation (Bernard Ramm), Interpreting the Bible (A. Berkeley Mickelsen), Biblical Interpretation (W. Randolph Tate) dan masih banyak yang lainnya.

${ }^{2}$ Lih. William Klein, Craig Blomberg, dan Robert Hubbard, Introduction to Biblical Interpretation (DallasLondon-Vancouver-Melbourne: Word, 1993), ix.

${ }^{3}$ Beberapa sarjana Injili belakangan ini sudah menaruh banyak perhatian kepada masalah ini, seperti Grant Osborne, The Hermeneutical Spiral: A Comprehensive Introduction to Biblical Interpretation (Downers Grove: InterVarsity, 1991), Milard Erickson, Evangelical Interpretation: Perspectives on Hermeneutical Issues (Grand Rapids: Baker, 1993), dan Walter Kaiser, Jr. dan Moisés Silva, An Introduction to Biblical Hermeneutics: The Search for Meaning (Grand Rapids: Zondervan, 1994).

${ }^{4}$ Anthony Thiselton, The Two Horizons: New Testament Hermeneutics and Philosophical Description (Exeter: Paternoster, 1981) dan Anthony Thiselton, The New Horizons in Hermeneutics: The Theory and Practice of Transforming Biblical Reading (Grand Rapids: Zondervan, 1992).
Pendekatan melalui peleburan dua horizon yang berbeda ini memungkinkan lahirnya sebuah horizon hermeneutis baru yang bersifat unik dan relevan bagi pembaca modern.

Dalam artikel ini, penulis berpendapat bahwa walaupun pendekatan hermeneutis yang dilakukan oleh Thiselton ini sangat komprehensif $^{5}$ dan serius dalam usaha menjembatani kesenjangan di atas, pendekatannya masih belum dapat menjawab isu-isu kontekstual. Pendekatan Thiselton secara khusus belum bisa menjawab tantangan dari antropologi lintas budaya, di mana secara budayawi horizon pembaca modern ternyata beragam, berlapis dan bersilang. Apalagi, dalam keadaan tertentu, berbeda sama sekali dengan horizon teks. Ini membuat makna teks kuno sulit dipahami pembaca/pendengar modern. Implikasinya, pendekatan hermeneutis peleburan dua horizon ini perlu mempertimbangkan kompleksitas isu lintas budaya dan terbuka terhadap kontribusi dari hermeneutika kontekstual yang lebih sensitif terhadap konteks. Kedua hal ini dapat menjadi addenda hermeneutica atau tambahan hermeneutis terhadap pendekatan peleburan horizon ini.

\section{HERMENEUTIKA PELEBURAN HORIZON-HORIZON: SEBUAH RETROSPEKSI SINGKAT}

Masalah klasik yang selalu muncul dalam wilayah penafsiran atau hermeneutika alkitabiah adalah bagaimana teks-teks yang ditulis pada masa lampau memiliki hubungan dan relevansi dengan para pembaca pada masa kini. ${ }^{6}$ Masalah ini juga telah mendorong banyak sarjana menggeluti, memikirkan sambil mencari solusi bersama seperti yang tampak pada gerakan penafsiran Perjanjian Baru the new hermeneutic, yang diprakarsai oleh

\footnotetext{
${ }^{5}$ Ia menggunakan banyak dimensi dalam ilmu penafsiran seperti teori-teori teks, semiotik dan literatur, pemakaian teori sosiokritikal, dan teori-teori hermeneutika utama (Ibid.).

${ }^{6}$ Anthony Thiselton, "The New Hermeneutic," dalam The New Testament Interpretations: Essays on Principles and Methods, ed. I. Howard Marshall (Grand Rapids: Eerdmans, 1977), 308.
} 
Fuchs dan Ebeling. ${ }^{7}$ Pertanyaan-pertanyaan pokok yang muncul dalam gerakan ini adalah bagaimana bahasa Alkitab dapat berbicara kepada pendengar modern? Bagaimana firman Allah itu menjadi firman "hidup" dan didengar secara baru? Menjawab pertanyaanpertanyaan ini bukan hal yang mudah, sebab antara teks dan pendengar terdapat jurang pemisah yang sangat lebar dan bersifat multidimensi, misalnya perbedaan dalam waktu, bahasa, dan kebudayaan.

Meskipun masalah ini sangat luas dan sulit diatasi, masih ada semacam optimisme bahwa kesenjangan ini masih dapat dijembatani. Beberapa pendapat yang setuju dengan hal ini muncul secara beragam, misalnya ada pendapat yang mengatakan bahwa walaupun frasa tradisional (baca: teks-teks kuno) itu diucapkan secara literal dan dalam konteks sejarah tertentu di masa lampau, tidak berarti hal tersebut hanya diperuntukkan untuk masa lampau. ${ }^{8}$ Teks-teks kuno ini masih dapat berbicara dan berhubungan dengan masa kini juga. Sementara itu, ada pendapat lain mengatakan bahwa kata yang sama (dari teksteks Alkitab) dapat disampaikan untuk waktu atau kesempatan yang berbeda dan dapat disampaikan dengan cara berbeda. ${ }^{9}$ Intinya, meskipun waktu dan kemasan berbeda, isi masih tetap sama.

Usaha yang paling ekstrem untuk menjembatani kesenjangan antara teks kuno dengan pendengar modern telah dilakukan oleh Rudolf Bultmann dengan program demitologisasinya. Program ini merupakan sebuah rekonstruksi radikal, yang muncul dari

\footnotetext{
${ }^{7}$ Ibid. Selain Fuchs dan Ebeling, ada juga para pemikir seperti Schleiermacher, Dilthey, Heidegger, Wittgenstein, Bultmann, dan Ricoeur yang prihatin dengan isu ini. Lih. Edgar McKnight, "Old and New Horizons in Hermeneutics: Anthony C. Thiselton on Contemporary Developments in Hermeneutic: A Review Article," Perspectives in Religious Studies 20, no. 3 (1997), 289-302.
}

${ }^{8}$ Wolfhart Pannenberg, Basic Questions in Theology (London: SCM, 1970), 1:9.

${ }^{9}$ Anthony Thiselton mengutip Gerhard Ebeling dalam "New Hermeneutic," A Guide to Contemporary Hermeneutics: Major Trends in Biblical Interpretation, ed. Donald McKim (Eugene: Wipf and Stock, 1999), 80. pemahaman bahwa manusia saintifik modern secara sederhana tidak dapat menerima pendeskripsian tradisional tentang hal-hal yang bersifat natural-supranatural. ${ }^{10}$ Pendapat ini menolak dari awal setiap tafsiran literal atau tradisional terhadap psikologi dan kosmologi Alkitab, sebab semua ini dianggap sudah ketinggalan zaman bagi manusia saintifik modern. Implikasinya, ada semacam usaha untuk menghilangkan unsur-unsur supraalamiah di dalam cerita-cerita injil yang dianggap sebagai mitos yang telah dikembangkan oleh orang-orang pada abad pertama. Dengan program ini, semua pesan atau kebenaran dalam injil dapat cocok (fit) dengan cara berpikir orang modern, sebab menurut Bultmann: "Our task is to discover the hermeneutical principle by which we understand what is said in the Bible. ${ }^{11}$ Kata "kami" di sini tentu merujuk kepada orang-orang modern yang berusaha mengerti teks-teks Alkitab kuno.

Usaha penyatuan teks Alkitab dan konteks pembaca atau penafsir modern di atas telah mencapai bentuk yang paling lengkap dalam teori the fusion of horizons yang digagaskan oleh Hans-Georg Gadamer. ${ }^{12}$ Di dalam perkembangan sejarah hermeneutika, telah muncul semacam spektrum yang membentang dari usaha hermeneutika yang berorientasi kepada teks (text-oriented) menuju kepada usaha yang berorientasi kepada pendengar (reader-oriented). Hal ini mengakibatkan jarak bentangan spektrum itu menjadi semakin lebar. Dalam konteks ini, Gadamer justru berupaya untuk memperkecil jarak spektrum ini dengan cara mendekatkan atau meleburkan kedua orientasi ini. Ia mengatakan bahwa

\footnotetext{
${ }^{10}$ Rudolf Bultmann, Kerygma and Myth, terj. Hans Werner Bartsch (New York: Harper and Row, 1961).

${ }^{11}$ Rudolf Bultmann, New Testament and Mythology, ed. dan terj. Schubert M. Ogden (Philadelphia: Fortress, 1984), 54. Bdk. Klein, Blomberg, dan Hubbard, Introduction to Biblical Interpretation, 48, 101.

${ }^{12}$ Inga Römer, "Method" dalam Blackwell Companion to Hermeneutics, ed. Niall Keane dan Chris Lawn (Chichester: Wiley-Blackwell, 2016), 90-91. Penjelasan lebih lengkap tentang teori ini dapat dilihat dalam karya Hans-Georg Gadamer, Truth and Method, ed. ke-2, terj. Joel Weinsheimer dan Donald G. Marshall (New York: Continuum, 2004).
} 
penafsiran bukan merupakan suatu tindakan subjektivitas seseorang melainkan suatu tindakan historis, di mana seorang penafsir menempatkan dirinya di dalam suatu proses tradisi, di mana masa lampau dan masa sekarang secara konstan melebur. ${ }^{13}$

Dalam teori ini, jarak antara subjek atau penafsir dan objek atau teks menjadi sangat temporal. Artinya, sifat yang temporal atau terbuka ini memberi ruang kepada penafsir untuk bergerak bebas menyaring prapemahaman (preunderstanding) atau tradisi historis teks sehingga ia dapat menyeleksi aspek-aspek yang bermakna dalam proses penafsiran. Berbeda dengan proses keilmuan objektif yang menolak preunderstanding dalam penafsiran, Gadamer justru menggunakan hal itu sebagai faktor yang positif, di mana prapemahaman itu dapat menjadi dasar bersama antara penafsir dengan situasi yang ada di dalam teks. Di tangannya, khususnya melalui teori peleburan horizon-horizonnya (the fusion of horizons), subjektivitas dan objektivitas menyatu, dan interpretasi menjadi suatu kegiatan aplikatif yang membuka pintu kemungkinan-kemungkinan penemuan horizon-horizon yang baru. ${ }^{14}$

\section{HERMENEUTIKA PELEBURAN DUA HORIZON ANTHONY THISELTON}

Perkembangan usaha untuk menjembatani kesenjangan antara teks dan pembaca atau penafsir di atas, secara khusus teori peleburan horizon-horizon (the fusion of horizons), secara tidak langsung telah melatarbelakangi gagasan hermeneutika peleburan dua horizon Anthony Thiselton. Berakar pada konsep peleburan horizon-horizon Gadamer, ia menggagaskan konsep yang mirip. ${ }^{15}$ Konsep

\footnotetext{
${ }^{13}$ Gadamer, Truth and Method, 258.

${ }^{14}$ Mark Taylor, Deconstructing Theology (Chico: Scholars, 1982), 48-49.

${ }^{15}$ Pada kenyataannya, selain dipengaruhi oleh Gadamer, pemikiran hermeneutis Thiselton juga berkorespondensi dengan pemikiran Wittgenstein, Heidegger, dan Bultmann. Lih. Robert Morgan, "Thiselton on Bultmann's Sachkritik" dalam Horizons in Hermeneutics: A Festschrift in Honor of Anthony C. Thiselton, ed. Stanley Porter dan Matthew Malcolm (Grand Rapids: Eerdmans, 2013), 33.
}

ini bertujuan sama: untuk menyatukan horizon pertama (teks-teks alkitabiah kuno) dengan horizon kedua (pembaca atau penafsir modern). Ini adalah suatu usaha untuk mencari arti teks dengan jalan membangun suatu kemajuan yang progresif menuju suatu kesatuan/peleburan horizon-horizon yang berhubungan, dan hal ini dapat dimungkinkan jika partikularitas setiap horizon secara penuh diperhitungkan dan dihargai. ${ }^{16}$

Thiselton sejak awal menekankan bahwa tujuan hermeneutika alkitabiah adalah untuk mempertemukan teks sebagai objek tafsir dan penafsir sebagai subjek penafsiran, di mana proses pertemuan atau penyatuan ini mensyaratkan suatu dinamika yang saling membentuk dan melebarkan kedua horizon. ${ }^{17}$ Di sini, hermeneutika menjadi sebuah cara hidup, belajar, peluasan dan penguasaan pengertian, dan pengembangan horizon si penafsir modern ketika membaca teks kuno. Melalui proses keterlibatan aktif yang bersifat dialogis (mensyaratkan kesabaran dan perhatian yang atentif) ini, horizon pemahaman si penafsir semakin melebar atau meluas. ${ }^{18}$ Seperti Gadamer, ia cukup optimistis bahwa, di satu sisi, kedua horizon ini dapat melebur, tetapi di sisi lain, secara praktis keduanya tidak dapat menjadi identik karena penafsir tidak dapat keluar dari tradisi historis di mana ia telah menjadi bagian di dalamnya. ${ }^{19}$

Dalam usaha ini, Thiselton tetap menyadari bahwa mencari objektivitas dengan cara peleburan adalah suatu hal yang tidak mungkin. Secara sederhana, hal ini berarti bahwa adalah sebuah kemustahilan untuk mengartikulasikan makna teks di dalam konteks historis yang asli, di dalam konteks yang kemudian, dan bahkan maknanya hari ini dalam hal kontinuitasnya. Karena itu, interpretasi selalu

${ }^{16}$ Thiselton, Two Horizons, 445.

${ }^{17}$ Ibid., xix.

${ }^{18}$ Anthony Thiselton, Hermeneutics of Doctrine (Grand Rapids: Eerdmans, 2007), xvii-xix; bdk. Kenneth Archer, "Horizons and Hermeneutics of Doctrine: A Review Essay," Journal of Pentecostal Theology 18, no. 1 (2009), 150-156.

${ }^{19}$ Ibid. 
harus dilihat dari sisi: then dan now, dua situasi historis yang berbeda dan bagaimana arti ini dapat melintas (transcend) di dalam kedua sisi ini. ${ }^{20}$ Baginya, manusia memiliki kemampuan untuk melakukan transendensi terhadap berbagai dimensi waktu yang berbeda dan merangkulnya menjadi satu kesatuan.

Lebih lanjut, Thiselton mengemukakan bahwa ada empat tingkatan yang mendukung kemustahilan menemukan objektivitas di dalam teks yang diistilahkan sebagai "ilusi objektivisme tekstual" (the illusion of textual objectivism). ${ }^{21}$ Pada tingkat hermeneutis, preunderstanding tidak dapat dipisahkan dari proses penafsiran dan elemen subjektif ini tidak dapat disangkal. Sementara itu, pada tingkat linguistik, ada jarak komunikasi yang sangat jauh antara teks dan penafsir. Padahal, suatu komunikasi memerlukan titik untuk bertemu sehingga arti teks memang tidak dapat diungkapkan. Selanjutnya, pada tingkat komunikasi sastra, menciptakan kembali konteks sastra yang orisinil di balik teks adalah hal yang tidak mungkin dilakukan. Akhirnya, pada tingkat filosofis, arti sebuah teks tidak pernah bebas dari konteksnya. Jadi, karena ada kesulitan untuk menemukan konteks, maka arti yang literal juga tidak mungkin didapatkan. ${ }^{22}$ Semua tingkatan ini menunjukkan bahwa ada kemustahilan untuk menemukan makna teks secara objektif.

Salah satu contoh sederhana dan konkret dari peleburan horizon Thiselton ini dapat dilihat dalam salah satu karya tafsirannya yang sangat masif, The First Epistle to the Corinthians dalam seri tafsiran NIGTC

\footnotetext{
${ }^{20}$ Kutipan korespondensi Larry Caldwell secara pribadi dengan A. Berkeley Mickelsen yang dimuat dalam artikelnya, "Cross-cultural Bible Interpretation: A View from the Field," Phronesis 3, no. 1 (1996), 16.

${ }^{21}$ Osborne, Hermeneutical Spiral, 386. Bdk. penjelasan lebih rinci dalam Anthony Thiselton, "The Bible and Today's Readers: 'The Two Horizons' and 'Pre-Understanding," dalam Thiselton on Hermeneutics: Collected Works and New Essays, ed. Anthony Thiselton (Aldershot: Ashgate, 2006), 441-462.
}

${ }^{22}$ Thiselton, Two Horizons, 1-4.
(The New International Greek Testament Commentary). ${ }^{23}$ Ketika menafsir 1 Korintus 1:10-11 yang menyoal tentang fragmentalisme yang terjadi di tengah jemaat Korintus, ia mampu menempatkan diri sebagai pembaca kekinian yang menanyakan pertanyaanpertanyaan hermeneutis yang meleburkan isu dalam horizon masa lampau ini dengan isu dalam horizon kekinian (pembaca pascamodern). Ini tampak dalam komentarnya:

Paul's example of communicative action in response to self-constructed perceptions of Corinthian peer groups is seen in relation to aspects of postmodernism; a postmodern pragmatism of the market with its related devaluation of truth, tradition, rationality, and universals.

Menyikapi pertanyaan tentang fragmentalisme dalam jemaat Korintus, ia mengasosiasikan keadaan tersebut dengan situasi pascamodern kekinian yang ditandai dengan pragmatisme pascamodern pasar dengan ciriciri: terjadinya devaluasi kebenaran, tradisi, rasionalitas dan hal-hal universal.

Dari bahasan ini, tampak bahwa peleburan dua horizon ini dapat menjadi jalan yang paling ideal dan cukup masuk akal untuk menjembatani kesenjangan antara teks dan konteks. Pernyataan ini tepat jika dilihat dari sisi filosofisnya dan nanti akan lebih ketat lagi diuji dari sisi antropologis, seperti yang akan dijelaskan dalam pembahasan berikut. Dari sisi antropologis, apa yang dilakukan oleh Thiselton dengan menggabungkan dua horizon itu lebih merupakan usaha menggabungkan dua kebudayaan: kebudayaan asli AlkitabPerjanjian Lama dan/atau Perjanjian Baru, dengan kebudayaan penafsir Alkitab yang modern. ${ }^{24}$ Namun, dari sini, masih ada persoalan yang tersisa: Apakah dengan demikian kedua kebudayaan akan disatukan? Kemudian, pertanyaan akan dibuat menjadi lebih dalam lagi: jika demikian, apakah mungkin

${ }^{23}$ Lih. tafsiran halaman 1446 Anthony C. Thiselton, The First Epistle to the Corinthians, NIGTC (Grand Rapids: Eerdmans, 2000), 33. 16. 
dua kebudayaan yang berbeda tempat, waktu dan jarak dapat dileburkan menjadi satu?

\section{TANTANGAN DARI ANTROPOLOGI LINTAS BUDAYA}

Meskipun usaha peleburan kedua horizon ini sangat positif dalam usaha menjembatani jurang pemisah antara teks kuno dengan pembaca modern, ada tantangan yang harus dicermati dalam pendekatan Thiselton di atas. Tantangan ini muncul dari kesenjangan hermeneutis (hermeneutical gap), terutama jarak budaya yang sangat jauh antara teks kitab suci dan konteks pembaca modern. Apalagi, pembaca modern di sini selalu dipahami sebagai baik penafsir teks (pemberita teks) maupun pendengar pemberitaan teks yang masingmasing memiliki budaya yang berbeda. Selain itu, tantangan berikutnya datang dari persoalan di dalam entitas metode peleburan itu sendiri. Tantangan ini akan dijelaskan pada dua bagian berikut ini.

Pertama, kemustahilan pembaca modern untuk memahami sepenuhnya kebudayaan asli Alkitab yang menyebabkan terjadinya kesulitan-kesulitan peleburan horizon-horizon yang berdimensi sejarah dan budaya ini. Thiselton mungkin kurang menyadari hal ini dalam mengembangkan teorinya. Ada hal-hal yang jauh berbeda yang harus dikonfrontasikan antara dua kebudayaan: kebudayaan teks kuno dan kebudayaan penafsir modern. Walaupun berasumsi bahwa akan terjadi komunikasi yang lancar antara kedua kebudayaan itu, ia sendiri tidak menunjukkan secara konkret dan pasti bagaimana kesenjangan itu dapat dijembatani dan diatasi melalui peleburan ini. Walaupun ada keoptimisan dalam hermeneutika dua horizon ini, tetap saja kenyataannya tidak demikian.

Berkaitan dengan hal ini, menurut teori antropologis tentang wawasan dunia (worldview), pandangan dunia dalam kebudayaan asli Alkitab tidak identik dengan pandangan dunia dalam kebudayaan penafsir. ${ }^{25}$ Ini dapat dilihat dalam Gambar 1.

Dari figur ini jelas bahwa bahwa ada semacam ketidakcocokan dalam pandangan dunia baik teks maupun konteks penafsir. Apalagi dalam konteks homiletis atau misiologis, ketidakcocokan ini semakin kuat ketika penafsir/pembaca ini memberitakan berita atau kerygma injil (makna teks) kepada pendengar yang mungkin memiliki kebudayaan yang jauh berbeda darinya. Karena adanya keberagaman dan keberlapisan konteks ini, maka akan muncul pengertian yang tidak lengkap dalam memahami kebudayaan asli Alkitab. Ini berlaku baik bagi si penafsir yang berbeda kebudayaan dari kebudayaan Alkitab maupun bagi si pembaca tafsiran yang hidup dalam kebudayaan yang berbeda dari si penafsir.

Kedua, masih berkaitan dengan masalah peleburan ini, kesenjangan antara teks dan konteks penafsir, dalam pengertian tertentu, tidak dapat dilakukan dengan cara peleburan. Pendekatan peleburan dua horizon yang digagas
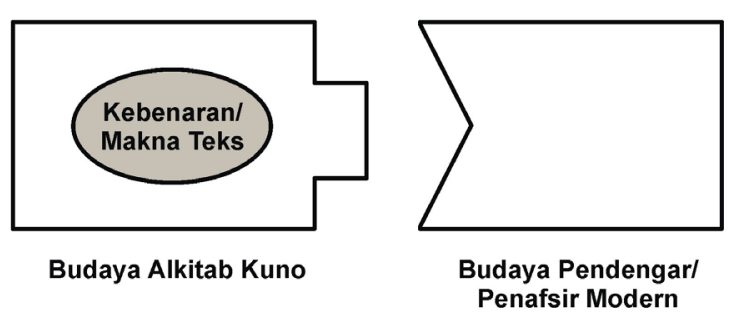

Gambar 1 Perbedaan Pandangan Dunia Kebudayaan Alkitab Kuno dengan Kebudayaan Penafsir Modern

${ }^{25}$ Lih. penjelasan David Hasselgrave, Communicating Christ Cross-Culturally: An Introduction to Missionary Communication (Grand Rapids: Zondervan, 1978), 76. 
Thiselton ini sejak awal memiliki setidaknya dua keterbatasan: pertama, ketidakmungkinan untuk menyatukan kedua horizon sejarah dan budaya ini; dan kedua, tidak ada sistem atau metode yang cukup efektif untuk menjembatani keduanya, yang masih valid yang dipakai untuk menemukan arti teks yang dimaksudkan. Ini termasuk cara atau metode peleburan. Karena itu, Osborne mengkritik metode bentuk circular dua horizon di atas dengan segala kelemahan, dan mengajukan bentuk spiral yang dianggapnya lebih efektif dan kontekstual. ${ }^{26}$

Karena dua tantangan ini, maka perlu ada semacam cara atau metode hermeneutis yang lebih bersifat redemptive daripada hanya sekadar yang bersifat lebur. Meskipun hermeneutika peleburan dua horizon dinilai dapat menjembatani kesenjangan hermeneutis, tampaknya hermeneutika tersebut tetap perlu terbuka juga untuk melihat hal-hal positif dari pendekatan hermeneutis yang lebih sensitif terhadap keberagaman, keberlapisan dan ketersilangan konteks budaya. Janz menegaskan bahwa hermeneutika yang demikian akan menolong: "Uncovering one's Vorurteile, or prejudices, inclinations, and blind-spots while at the same time establishing the basis for reciprocal understanding." 27 Ada semacam sikap kritis sekaligus dialogis dalam hermeneutika yang demikian. Melalui pendekatan yang seperti ini, akan terjadi dialektika yang dinamis, berkelanjutan dan transformatif antara teks kuno dan konteks penafsir, pembaca dan, bahkan, pendengar modern. Ini hanya dapat dilakukan dan terjadi melalui proses kontekstualisasi.

Sayangnya, walaupun teks dan konteks adalah dua komponen yang penting dalam proses kontekstualisasi, ${ }^{28}$ kedua hal ini telah terpola-

\footnotetext{
${ }^{26}$ Osborne, Hermeneutical Spiral, 395.

${ }^{27}$ Bruce Janz, "Hermeneutics and Intercultural Understanding," dalam Routledge Companion to Hermeneutics," ed. Jeff Malpas dan Hans-Helmuth Gander (London/New York: Routledge, 2015), 476.

${ }^{28}$ Charles Kraft menggunakan istilah eternal (absolute) truths dan cultural (relative) truths untuk kedua komponen ini. Lihat Charles Krafazt, "Towards A Christian
}

risasi sedemikian rupa. Penekanan terhadap satu kutub mengakibatkan pengabaian terhadap kutub yang lain, dan sebaliknya. Contoh yang nyata dapat dilihat dalam ketegangan yang muncul, khususnya dalam metode hermeneutis yang dipakai oleh kelompok ekumenikal dan evangelikal. Ini, kemudian, berimbas pada bagaimana cara masing-masing menjalankan misi dan kontekstualisasi injil. Gerakan ekumenikal lebih menekankan usaha kontekstualisasi yang berangkat dari konteks. Sementara itu, gerakan evangelikal (Injili) lebih menekankan usaha kontestualisasi yang berangkat dari teks. ${ }^{29}$

\section{ADDENDA HERMENEUTICA TERHADAP PELEBURAN DUA HORIZON}

Di atas telah dijelaskan kesulitan-kesulitan dalam teori peleburan dua horizon Thiselton, khususnya ketika berhadapan dengan tantangan yang muncul dari antropologi lintas budaya. Karena itu, gagasan baru yang lebih menjawab persoalan, kreatif dan kontekstual seharusnya dapat dipikirkan dan diajukan sehingga dapat memberi terobosan baru dalam pengembangan hermeneutika kekinian. Dalam konteks ini, penulis meletakkan diri sebagai "orang Injili" yang ingin mengajukan pertimbangan yang dapat digunakan sebagai tambahan (baca: pelengkap) hermeneutis atau addenda hermeneutica terhadap pendekatan dua horizon di atas. Pertimbangan Injili ini akan berfokus kepada baik asumsi-asumsi teologis maupun proses kontekstualisasi hermeneutis Injili.

Beberapa pendekatan kreatif telah diajukan, seperti apa yang telah dilakukan beberapa sarjana Injili seperti Osborne dengan "spiral hermeneutisnya," 30 Carson dengan "horizon

Ethnotheology," God, Man, and Church Growth, ed. Alan Tippett (Grand Rapids: Eerdmands, 1973), 110.

${ }^{29}$ Wilson Chow, "Biblical Foundation: An East Asian Study," Evangelical Review of Theology 7, no. 1 (1983), 106.

${ }^{30}$ Lih. seluruh argumentasinya dalam Grant R. Osborne, The Hermeneutical Spiral: A Comprehensive Introduction to Biblical Interpretation (Downers Grove: InterVarsity, 1991). 
ketiganya,"31 atau Caldwell dengan "etnohermeneutikanya." 32 Apapun nama atau istilah yang dipakai untuk hermeneutika Injili kontekstual yang demikian, ada beberapa prinsip atau acuan yang sama dan mendasar: pertama, hermeneutika ini menghargai teks sebagai sumber otoritasnya. Kesetiaan kepada pesan firman Tuhan yang utuh harus diutamakan; kedua, hermeneutika ini memperhatikan konteks pembaca, penafsir atau penerima tangan kedua atau ketiga secara serius dan proporsional sehingga pesan firman Tuhan bukan sesuatu yang ada hanya di awan-awan; dan ketiga, hermeneutika memiliki fleksibilitas dan konsistensi dalam bergerak, dari teks kuno menuju ke konteks modern. "Fleksibel" di sini berarti mampu beradaptasi dengan konteks yang ada, sementara "konsisten" berarti mampu untuk tetap setia pada prinsip-prinsip penafsiran yang alkitabiah. Bartholomew menegaskan bahwa hermeneutika "Injili" pada dasarnya adalah usaha untuk mendengar Allah secara serius berbicara (di hadapan-Nya atau Coram Deo) di dalam Kitab Suci kepada semua konteks kehidupan. ${ }^{33}$

Karena substansi hermeneutika yang demikian ada pada natur Alkitab dan proses kontekstualiasinya, maka perlu ada semacam pemahaman terhadap hubungan antara

${ }^{31}$ Lih. penjelasan lebih lengkap tentang hal ini dalam artikel D.A. Carson, "Church and Mission: Reflections on Contextualization and the Third Horizon," The Church in the Bible and in the World: An International Study, ed. D.A. Carson (Exeter/Grand Rapids: Paternoster/Baker, 1987).

${ }^{32}$ Ia menggunakan istilah "etnohermeneutik" untuk merujuk kepada hermeneutika yang sensitif terhadap konteks budaya reseptor (receptor culture). Lih. Larry Caldwell, "Toward Ethnohermenuetics: Contextualization 2.0 and Beyond," Didaktikos Journal (2018): 37-38. Bdk. juga beberapa tulisannya: "Third Horizon Ethnohermeneutics: Re-evaluating New Testament Hermeneutical Models for Intercultural Bible Interpreters Today," Asia Journal of Theology 1, no. 1 (1987): 314-333; "Cross-cultural Bible Interpretation: A View from the Field," Phronesis 3, no. 1 (1996): 24-31; dan "Toward a New Discipline of Ethnohermeneutics: Questioning the Relevancy of Western Hermeneutical Methods in the Asian Context," Journal of Asian Mission 1, no. 1 (1999): 21-43.

${ }^{33}$ Craig Bartholomew, Introducing Biblical Hermeneutics: A Comprehensive Work for Hearing God in the Scripture (Grand Rapids: Baker Academic, 2015), 14. kedua hal tersebut. Maksudnya, ini berkaitan dengan hubungan antara Alkitab (yang teks kunonya ditafsir dan maknanya diberitakan) dan proses bagaimana makna ini sampai di telinga si pendengar berita teks yang memiliki konteks budaya yang berbeda dari si pemberita. Van der Merwe mengatakan, "Faith, spirituality and culture become hermeneutical tools in the understanding process." 34 Selain iman dan spiritualitas pembaca teks, budaya pembaca juga dapat menjadi alat penafsiran dalam memahami makna teks. Ini berarti bahwa konteks (budaya) di sini dapat menjadi salah satu sumber interpretatif baik bagi si penafsir maupun si pendengar. Holter selanjutnya menegaskan bahwa "The Bible is today interpreted all over the globe by people who consciously make use of their context as interpretative resources." ${ }^{35}$ Karena itu hermeneutika yang sensitif terhadap kompleksitas konteks bukan hanya berusaha mencari makna teks secara teoretis atau konseptual, tetapi juga menerapkannya secara praktis dalam konteks pergumulan hidup dan pelayanan orang Kristen dan gereja.

Secara praktis, kontekstualisasi memiliki beberapa manfaat bagi orang Kristen dan gereja. Whiteman mengusulkan tiga fungsi kontekstualisasi dalam konteks demikian: pertama, fungsi konstruktif. Tentang hal ini ia berkata bahwa "contextualization attempts to communicate the Gospel in word and deed and to establish the church in ways that make sense to people within their local cultural context, presenting Christianity in such a way that it meets people's deepest needs and penetrates their worldview, thus allowing them to follow Christ and remain within their own culture." 36 Fungsi konstruktif ini sangat menekankan

\footnotetext{
${ }^{34}$ Dirk van der Merwe, "Reading the Bible in the $21^{\text {st }}$ Century: Some Hermeneutical Principle-Part 2," Verbum et Ecclesia 36, no. 1 (2015), 2.

${ }^{35}$ Knut Holter, "When Biblical Scholar Talks about 'Global' Biblical Interpretation," dalam Global Hermeneutics: Reflections and Consequences, ed. Knut Holter dan Lois Jonker (Atlanta: Society of Biblical Literature, 2010), 93.

${ }^{36}$ Darell Whiteman, "Contextualization: The Theory, the Gap, the Challenge," International Bulletin of Missionary Research 21, no. 1 (1997): 2-7.
} 


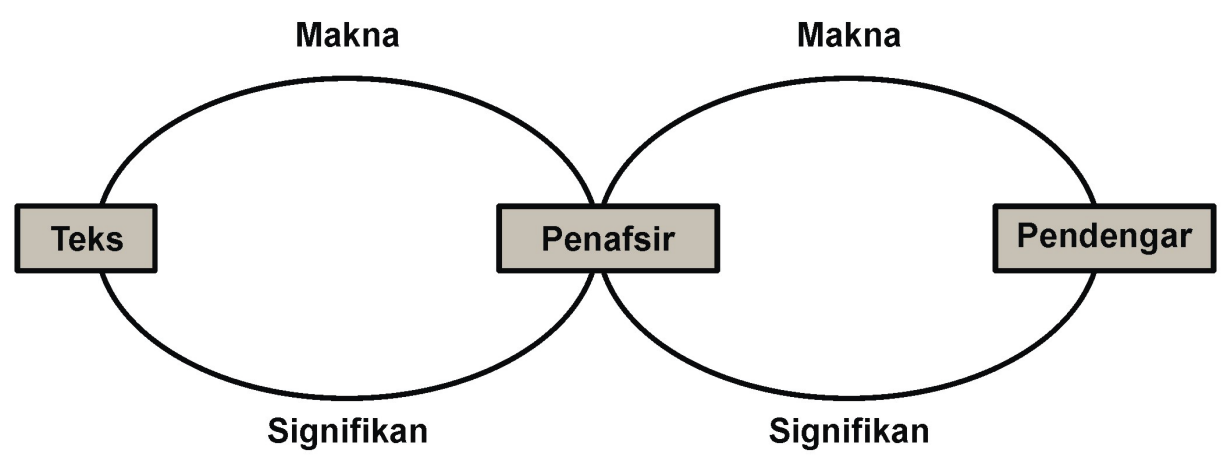

Gambar 2 Spiral Hermeneutis

usaha atau cara untuk memberitakan injil supaya gereja dapat didirikan. Bahkan, usaha kontekstualisasi juga dapat menjadikan pesan dan kesaksian gereja diterima dan berdampak dalam kebudayaan lokal. Kontekstualisasi dapat mewujudkan pemuridan yang berakar pada konteks budaya lokal.

Kedua, fungsi transformatif. Whiteman menjelaskan bahwa fungsi kedua dari kontekstualisasi adalah fungsi untuk mengancam (to offend), dalam pengertian bahwa hal ini dilakukan dengan alasan-alasan yang benar, bukan sebaliknya dengan alasan-alasan yang salah. Tidak dapat dipungkiri, injil selalu bersifat konfrontatif. Injil dapat mengancam apa saja yang terdapat dalam kebudayaan, yang bertentangan dengan nilai-nilai kerajaan Allah. Injil akan terang-terangan membuka kedok-kedok keberdosaan dan kejahatan masyarakat, dan bukan itu saja, kuasanya juga akan mengubah struktur-struktur yang menindas dan pola-pola kebiasaan yang salah dalam budaya dan masyarakat tertentu. ${ }^{37}$ Dengan kata lain, ancaman yang konfrontatif jika dilakukan dengan alasan yang tepat dan benar dapat menghasilkan transformasi.

Ketiga, fungsi ekspresif. Fungsi kontekstualisasi yang terakhir adalah untuk mengembangkan ekspresi-ekspresi injil yang terkontekstualisasi sehingga injil itu dapat dimengerti dengan cara yang belum pernah dialami dan dimengerti oleh gereja secara universal. ${ }^{38}$ Injil

\footnotetext{
${ }^{37}$ Ibid.

${ }^{38} \mathrm{Ibid}$.
}

yang dikontekstualisasikan akan memiliki ekspresi-ekspresi yang unik dan signifikan di dalam dan bagi budaya tertentu. Dengan demikian, kekristenan yang dihasilkan adalah bercirikan konteks setempat. Tantangan dalam fungsi ini adalah bagaimana membangun komunitas Kristen yang, pada saat yang sama, setia kepada warisan sejarah dan budaya mereka. Peter Schineller menekankan hal ini dengan mengatakan, "Every local Christian community must maintain its links with other communities in the present around the world, and with communities of the past, through an understanding of Christian tradition." 39 Relasi antarkomunitas yang saling berkoneksi dan berkomunikasi mensyaratkan isi pesan yang dapat saling dimengerti.

Meski ketegangan yang demikian tidak mudah untuk diatasi, dari perspektif Injilinya, penulis yakin bahwa kontekstualisasi yang berangkat dari teks akan lebih bertanggung jawab secara hermeneutis daripada yang berangkat dari konteks. Keyakinan ini didasari atas pendekatan penafsiran teks yang alkitabiah dan dinamis, yang sering disebut spiral hermeneutis (hermeneutical spiral), ${ }^{40}$ sebagaimana dijelaskan dalam Gambar 2.

Pendekatan hermeneutika kontekstualisasi seperti ini dimulai dari teks sebagai sumber atau titik berangkat yang memberikan

\footnotetext{
${ }^{39}$ Peter Schineller, $A$ Handbook on Inculturation (New York: Paulist, 1990), 72.

${ }^{40}$ Prinsip hermeneutical spiral dikemukakan oleh Osborne, dan skema ini diadaptasi dari karyanya Osborne, The Hermeneutical Spiral, 325.
} 
Dekulturalisasi

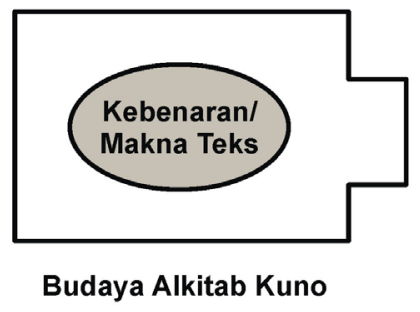

Rekulturalisasi

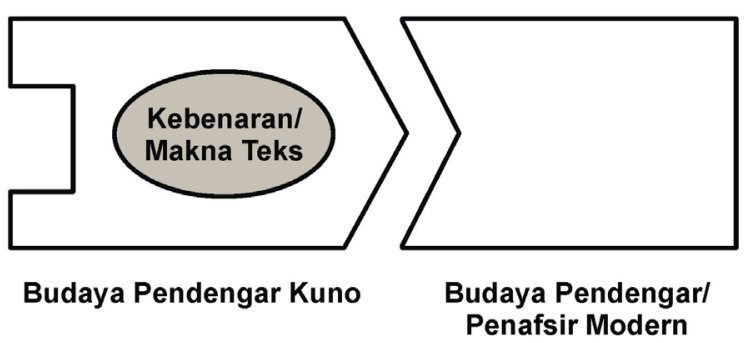

Gambar 3 Proses Dekulturalisasi dan Rekulturalisasi

signifikansi kepada penafsir, kemudian penafsir memberi arti/makna kepada teks. Setelah proses ini berlangsung, penafsir yang kemudian menjadi pemberita memberi signifikansi kepada budaya penerima (pendengar), yang kemudian memberi arti kepada penafsir (pemberita). ${ }^{41}$ Dalam proses kontekstualisasi yang demikian, komunikasi injil terjalin secara dinamis, melingkar dan bertanggung jawab. Kerigma (berita injil/firman Tuhan) bukan saja memengaruhi si pemberita, tetapi lebih jauh juga akan memengaruhi si penerima. Schneiders menegaskan bahwa, "The objective of interpretation ought to be the dialectical illumination of the meaning of the text as well as '. . the self-understanding of the reader." 42 Teks dan konteks dapat saling berhubungan dan memengaruhi satu dengan yang lain secara dialektis.

Secara praktis, sebagai suatu proses komunikasi yang dinamis ini, kontekstualisasi mensyaratkan dua macam proses: dekulturalisasi (deculturalization) dan rekulturalisasi (reculturalization). Kedua proses ini diperlukan karena pendengar yang menerima kebenaran sangat berhubungan dengan dan tidak dapat dipisahkan dari budaya asalnya. Secara antropologis, semua bahasa, simbol, pola pikir dan pandangan dunia adalah telah ditentukan (culturally determined), sehingga manusia tidak dapat mengenal, memahami dan menerapkan kebenaran terpisah dari

\footnotetext{
${ }^{41}$ Ibid.

${ }^{42}$ Seperti yang dikutip oleh Van der Merwe, "Reading the Bible in the $21^{\text {st }}$ Century," 2.
}

kebudayaan. ${ }^{43}$ Kedua proses ini dapat dijelaskan dalam Gambar 3.

Kebenaran kekal yang dibungkus dengan bentuk budaya Alkitab tidak dapat langsung diterapkan ke dalam konteks budaya pembaca atau penafsir, karena itu perlu adanya proses dekulturalisasi, di mana bentuk-bentuk budaya Alkitab yang membungkus kebenaran kekal diminimalisasi tanpa menghilangkan kebenaran kerigma, kemudian dirancang proses rekulturalisasi, di mana kerygma (berita injil/firman Tuhan) ini kemudian akan dibungkus dalam bentuk baru sehingga dapat diterima oleh penerima pesan itu dalam budaya dan masa yang berbeda. Proses kontekstualisasi di atas dapat berlanjut atau bergerak terus sejauh adanya bentangan lapisan konteks yang beragam, berlapis dan melintas. Hanya melalui proses formulasi pendekatan yang hidup dan dinamis seperti ini orangorang pada masa kini dapat lebih bertumbuh atau maju ke arah kuasa yang suprakultural dan ke arah tuntutan-tuntutan Alkitab (kebenaran/makna teks). ${ }^{44}$

\section{KESIMPULAN}

Pendekatan hermeneutika peleburan dua horizon (the fusion of two horizons) yang dilakukan oleh Thiselton adalah sangat baik dan patut diapresiasi. Pendekatan ini bereaksi secara positif terhadap polarisasi teks dan

\footnotetext{
${ }^{43}$ Wing-Luk Seto, "An Asian Looks at Contextualization and Developing Ethnotheologies," Evangelical Missionary Quarterly 23, no. 2 (1987), 138.

${ }^{44}$ Ibid., 139.
} 
konteks yang sudah berlangsung berabadabad. Di samping itu, pendekatan ini juga sangat concern terhadap kesenjangan antara teks dan konteks pembaca, penafsir, atau penerima tangan kedua atau ketiga, dengan berusaha untuk menjembatani kesenjangan itu. Sebagai suatu langkah awal, pendekatan hermeneutika yang efektif dan relevan, hermeneutika peleburan horizon ini dapat menjadi titik berangkat yang baik.

Sayangnya, hermeneutika yang demikian hanya dapat dilakukan dalam suatu penafsiran yang memiliki kondisi budaya yang monolitik atau tunggal (monocultural interpretation). Jika diperhadapkan dengan isu lintas budaya, khususnya dalam konteks penafsiran yang memiliki budaya yang beragam, berlapis dan bersilang, maka pendekatan Thiselton ini menjadi kurang efektif dan relevan. Hal ini disebabkan oleh keterbatasan pendekatan ini untuk memperhatikan masalah lintas budaya, khususnya mengabaikan elemen ketiga yang sangat krusial, yaitu penerima-penerima berita yang ketiga (bdk. "the third horizon" yang dipakai Carson). Selain kurang dapat menjelaskan hubungan teks (first horizon) dan penafsir (second horizon), pandangan Thiselton ini juga kurang jelas dalam menghubungkan kedua hal itu (teks dan penafsir) dengan penerima-penerima tafsiran dalam konteks lintas budaya, yaitu para pembaca di budaya yang ketiga (third horizon).

Untuk mengatasi kekurangan-kekurangan yang dimiliki oleh metode hermeneutika peleburan horizon (the fusion of horizons) ini, artikel ini telah mengajukan sebuah addenda hermeneutica yang secara proporsional menekankan sisi konteks dalam bentuk kontekstualisasi. Ini merupakan sebuah cara untuk menjembatani kesenjangan antara kedua horizon, dan bahkan dapat menjembatani horizonhorizon yang lain (other horizons) yang akan dijumpai dalam pemberitaan atau pengajaran injil (firman Allah). Diharapkan, melalui diskusi ini, berbagai pendekatan hermeneutika kontekstual yang lebih baru dan kreatif dapat bermunculan, sebagai suatu usaha yang lebih serius untuk dapat mengatasi kesenjangan antara teks Alkitab kuno dan konteks pembaca modern. Dengan demikian, kerygma atau berita injil (firman Allah) dapat sampai kepada dan dimengerti oleh semua orang dalam berbagai konteks budaya tanpa kendala-kendala sosiokultural.

\section{DAFTAR KEPUSTAKAAN}

Archer, Kenneth. "Horizons and Hermeneutics of Doctrine: A Review Essay." Journal of Pentecostal Theology 18, no. 1 (2009): 150-156.

Bartholomew, Craig. Introducing Biblical Hermeneutics: A Comprehensive Work for Hearing God in the Scripture. Grand Rapids: Baker Academic, 2015.

Butmann, Rudolf. Kerygma and Myth, diterjemahkan oleh Hans Werner Bartsch. New York: Harper and Row, 1961.

- New Testament and Mythology, diedit dan diterjemahkan oleh Schubert M. Ogden. Philadelphia: Fortress, 1984.

Caldwell, Larry. "Third Horizon Ethnohermeneutics: Re-evaluating New Testament Hermeneutical Models for Intercultural Bible Interpreters Today." Asia Journal of Theology 1, no. 1 (1987): 314-333.

. "Cross-cultural Bible Interpretation: A View from the Field." Phronesis 3, no. 1 (1996): 13-35.

_. "Toward a New Discipline of Ethnohermeneutics: Questioning the Relevancy of Western Hermeneutical Methods in the Asian Context." Journal of Asian Mission 1, no. 1 (1999): 21-43.

—. "Toward Ethnohermenuetics: Contextualization 2.0 and Beyond," Didaktikos Journal (2018): 37-38.

Carson, D.A. "Church and Mission: Reflections on Contextualization and the Third Horizon." Dalam The Church in the Bible and in the World: An International Study, diedit oleh D.A. Carson, 213-345. Exeter/ Grand Rapids: Paternoster/Baker, 1987. 
Chow, Wilson. "Biblical Foundation: An East Asian Study." Evangelical Review of Theology 7, no. 1 (1983): 34-47.

Erickson, Millard. Evangelical Interpretation: Perspectives on Hermeneutical Issues. Grand Rapids: Baker, 1993.

Gadamer, Hans-Georg. Truth and Method. Ed. ke-2. Diterjemahkan oleh Joel Weinsheimer dan Donald G. Marshall. New York: Continuum, 2004.

Hesselgrave, David. Communicating Christ Cross-Culturally: An Introduction to Missionary Communication. Grand Rapids: Zondervan, 1978.

Holter, Knut. "When Biblical Scholar Talks about 'Global' Biblical Interpretation." Dalam Global Hermeneutics: Reflections and Consequences, diedit oleh Knut Holter dan Lois Jonker, 85-93. Atlanta: Society of Biblical Literature, 2010.

Janz, Bruce. "Hermeneutics and Intercultural Understanding." Dalam Routledge Companion to Hermeneutics," diedit oleh Jeff Malpas dan Hans-Helmuth Gander, 474485. London/New York: Routledge, 2015.

Kaiser, Walter, Jr. and Silva, Moisés. An Introduction to Biblical Hermeneutics: The Search for Meaning. Grand Rapids: Zondervan, 1994.

Klein, William L., Craig L. Blomberg, dan Robert L. Hubbard. Introduction to Biblical Interpretation. Dallas/London/Vancouver/Melbourne: Word, 1993.

Kraft, Charles H. "Towards A Christian Ethnotheology." Dalam God, Man, and Church Growth, diedit oleh Alan R. Tippett, 109-126. Grand Rapids: Eerdmans, 1973.

McKnight, Edgar. "Old and New Horizons in Hermeneutics: Anthony C. Thiselton on Contemporary Developments in Hermeneutic: A Review Article." Perspectives in Religious Studies 20, no. 3 (1997): 289-302.
Morgan, Robert. “Thiselton on Bultmann's Sachkritik." Dalam Horizons in Hermeneutics: A Festschrift in Honor of Anthony C. Thiselton, diedit oleh Stanley Porter dan Matthew Malcolm, 32-50. Grand Rapids: Eerdmans, 2013.

Osborne, Grant R. The Hermeneutical Spiral: A Comprehensive Introduction to Biblical Interpretation. Downers Grove: InterVarsity, 1991.

Pannenberg, Wolfhart. Basic Questions in Theology. London: SCM, 1970.

Römer, Inga. "Method." Dalam Blackwell Companion to Hermeneutics, diedit oleh Niall Keane dan Chris Lawn, 86-95. Chichester: Wiley-Blackwell, 2016.

Schineller, Peter. A Handbook on Inculturation. New York: Paulist, 1990.

Seto, Wing-Luk, "An Asian Looks at Contextualization and Developing Ethnotheologies." Evangelical Missionary Quarterly 23, no. 2 (1987): 138-141.

Taylor, Mark. Deconstructing Theology. Chico: Scholars, 1982.

Thiselton. Anthony. "The New Hermeneutic." Dalam The New Testament Interpretations: Essays on Principles and Methods, diedit oleh I. Howard Marshall, 308-333. Grand Rapids: Eerdmans, 1977.

. The Two Horizons: New Testament Hermeneutics and Philosophical Description. Exeter: Paternoster, 1981.

_. "The New Hermeneutic." Dalam A Guide to Contemporary Hermeneutics: Major Trends in Biblical Interpretation, diedit oleh Donald McKim, 78-107. Grand Rapids: Eerdmans, 1986.

- The New Horizons in Hermeneutics: The Theory and Practice of Transforming Biblical Reading. Grand Rapids: Zondervan, 1992.

. The First Epistle to the Corinthians, NIGTC. Grand Rapids: Eerdmans, 2000. 
"The Bible and Today's Readers:

'The Two Horizons' and 'Pre-Understanding." Dalam Thiselton on Hermeneutics: Collected Works and New Essays, diedit oleh Anthony Thiselton, 441-463. Aldershot: Ashgate, 2006.

Hermeneutics of Doctrine. Grand Rapids: Eerdmans, 2007.
Van der Merwe, Dirk. "Reading the Bible in the 21st Century: Some Hermeneutical Principle-Part 2." Verbum et Ecclesia 36, no. 1 (2015): 1-7.

Whiteman, Darell. "Contextualization: The Theory, the Gap, the Challenge." International Bulletin of Missionary Research 21, no. 1 (1997): 2-7. 